\title{
Freshwater aquatic invertebrates on the Isle of May, Scotland
}

\author{
C.R. Macadam \\ Buglife Scotland, Balallan House, 24 Allan Park, Stirling FK8 2QG \\ E-mail: craig.macadam@buglife.org.uk
}

\begin{abstract}
The invertebrate fauna of freshwater habitats on the Isle of May, Scotland was investigated and compared with the results from surveys undertaken in 1958. Overall, the freshwater invertebrate fauna appears to be diminished. However, several species were recorded as new to the Isle of May. Although the reasons for the apparent decline in freshwater invertebrates on the island are unclear, an increase in the temporary nature of the habitats due to climate warming may be a contributing factor.
\end{abstract}

\section{INTRODUCTION}

The Isle of May is located approximately $8 \mathrm{~km}$ south-east of the mainland at Anstruther in Fife, Scotland, lying roughly north-west to south-east in the mouth of the Firth of Forth. The island is $1.8 \mathrm{~km}$ long by $0.5 \mathrm{~km}$ wide and is 57 ha in area. The east side of the island is characterised by a low-lying rocky coastline whilst the west side is dominated by high cliffs. The island is currently owned and managed by NatureScot (formerly known as Scottish Natural Heritage). Staff from NatureScot stay on the island every summer along with several research students to manage the island and conduct scientific research on nesting seabirds.

The Isle of May is renowned for its internationally important populations of breeding seabirds and grey seals (Halichoerus grypus) and its sub-tidal reefs, as well as being nationally important for its population of wintering waders (Pickett \& Luurtsema, 2014). The island is heavily protected because of this and is a National Nature Reserve as well as being in a European Special Protection area for its breeding seabirds, and a Special Area of Conservation for seals, and it lies in the Forth Islands Special Protection Area. A bird observatory opened on the island in 1934, and scientific studies on several species of seabirds that nest on the island, including puffin (Fratercula arctica), kittiwake (Rissa tridactyla), shag (Phalacrocorax aristotelis) and eider duck (Somateria mollissima), began in 1966 (Pickett \& Luurtsema, 2014).

The earliest record of aquatic invertebrates on the Isle of May is of the brackish-water amphipod Gammarus duebeni and the seed shrimp Heterocypris incongruens, which were recorded in pools on the island in the 1890 s (Scott, 1906). Invertebrates are, however, underrecorded on the Isle of May and few recent surveys have been undertaken. Eggeling (1960) summarised the records of species, including those from freshwater habitats, from the Isle of May. These include adult records of the dragonflies Sympetrum fonscolombii and Aeshna juncea reported by Evans (1912) and Eggeling $(1956,1957)$, and records of adult caddisflies attracted to the lamp of the lighthouses on the island (Evans 1915a,b). These species are all strong flyers and the individuals reported almost certainly originated from the mainland, as suitable habitat for their juvenile stages is absent on the Isle of May. Maitland (1967) provided the first comprehensive investigation of the aquatic fauna of the Isle of May following surveys undertaken in 1958. In August 2012 a team of four individuals from Buglife - The Invertebrate Conservation Trust spent three days (1st-3rd August) on the Isle of May to undertake surveys of invertebrates in various habitats present on the island. This paper describes the results of surveys of freshwater habitats on the island.

\section{METHODS}

Maitland (1967) identified 26 freshwater sites separated into six areas on the island (Fig. 1; Table 1). Several water bodies reported by Maitland (1967) were not found (Table 1), or were devoid of water (Fig. 1: stations c, q and r), possibly as a result of the extended spell of dry, warm weather that preceded the surveys in 2012. In addition, the location of the two springs identified by Maitland (1967) (Fig. 1: stations $t$ and $u$ ) were located though they were not flowing at the time of these surveys. None of the wells on the island (Fig. 1: stations $\mathrm{v}$ to $\mathrm{z}$ ) were sampled, to prevent disturbance of the water supply. However, a further two small ponds were located during this study in the area known as West Braes (Fig. 1):

Station aa. West Braes Pond 1 (9.8 m x 7.9 m; 0.2-0.3 m deep) is a located in the area known as West Braes, overlooking Fluke Street and the Loch. The southern bank of this pond is comprised of a rock face approximately $1 \mathrm{~m}$ high and it is here that the water is at its deepest (Fig. 2). The water of this pond was clear at the time of sampling and the bed is made up of pockets of soft sediments and some patches of shoreweed (Littorella uniflora). There are also small clumps of small sweet grass (Glyceria declinata) and common water starwort (Callitriche stagnalis) present. 


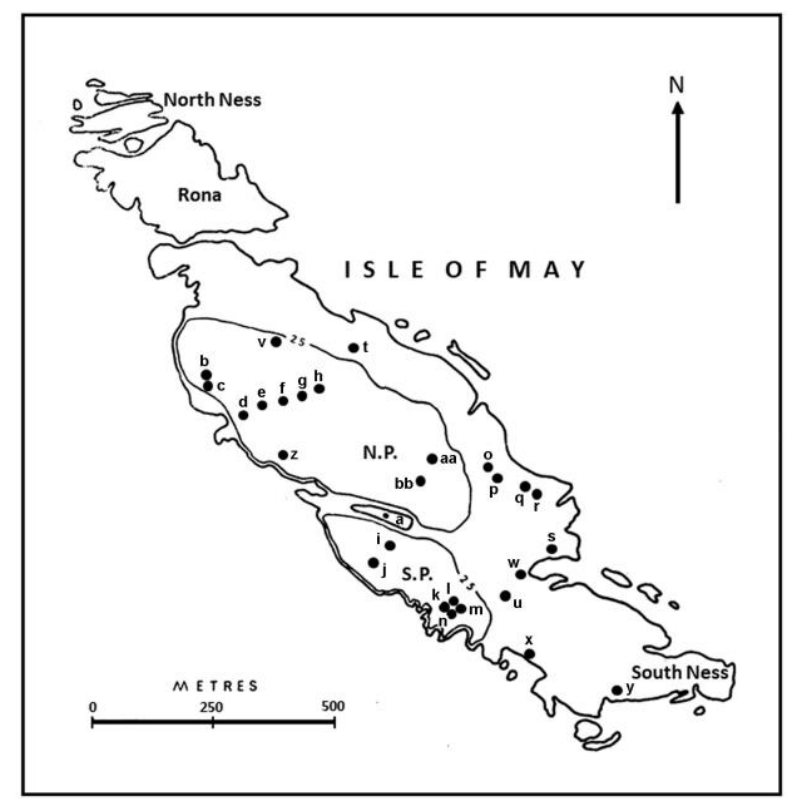

Fig. 1. Outline map of the Isle of May, Scotland showing the location of the water bodies mentioned in the text. Adapted from Maitland (1967).

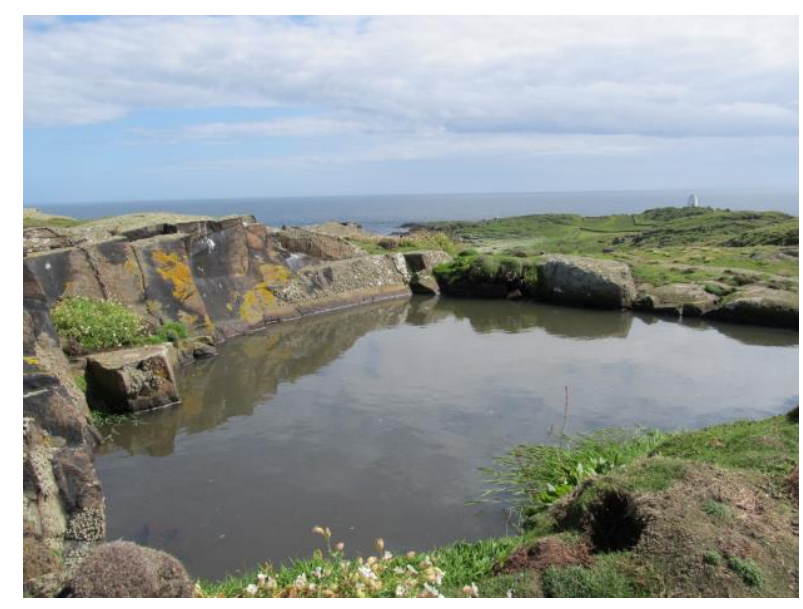

Fig. 2. West Braes Pond 1 (aa), Isle of May, Scotland. (Photo: C.R. Macadam)

\begin{tabular}{lllll}
\hline Code & Maitland Name & Current Name & Grid Reference & $\begin{array}{l}\text { Sampled in } \\
\text { this study }\end{array}$ \\
\hline $\mathrm{a}$ & The Loch & The Loch & NT6564599206 & Yes \\
$\mathrm{b}$ & North Plateau Pool I & & Not found & No \\
$\mathrm{c}$ & North Plateau Pool II & & NT6524599480 & No \\
$\mathrm{d}$ & North Plateau Pool III & Three Tarn Nick Pond 1 & NT6538199477 & Yes \\
$\mathrm{e}$ & North Plateau Pool IV & Three Tarn Nick Pond 2 & NT6536699470 & Yes \\
$\mathrm{f}$ & North Plateau Pool V & Three Tarn Nick Pond 3 & NT6535199464 & Yes \\
$\mathrm{g}$ & North Plateau Pool VI & Three Tarn Nick Pond 4 & NT6533899458 & Yes \\
$\mathrm{h}$ & North Plateau Pool VII & Three Tarn Nick Pond 5 & Not found & No \\
$\mathrm{i}$ & South Plateau Pool I & High Tarn Pond 2 & NT6557799169 & Yes \\
$\mathrm{j}$ & South Plateau Pool II & High Tarn Pond 1 & NT6554499121 & Yes \\
$\mathrm{k}$ & South Plateau Pool III & Cornerstone Pond 4 & NT6572899011 & Yes \\
l & South Plateau Pool IV & Cornerstone Pond 3 & NT6574899015 & Yes \\
$\mathrm{m}$ & South Plateau Pool V & Cornerstone Pond 2 & NT6575398985 & Yes \\
$\mathrm{n}$ & South Plateau Pool VI & Cornerstone Pond 1 & NT6577199005 & Yes \\
$\mathrm{o}$ & East Pool I & & Not found & No \\
$\mathrm{p}$ & East Pool II & & Not found & No \\
$\mathrm{q}$ & East Pool III & & NT6589699257 & No \\
$\mathrm{r}$ & East Pool IV & NT6593999220 & No \\
$\mathrm{s}$ & East Pool V & & Not found & No \\
$\mathrm{t}$ & Spring I & NT6548099558 & No \\
$\mathrm{u}$ & Spring II & NT6581399006 & No \\
$\mathrm{v}$ & Well I & Spring I & NT6537599592 & No \\
$\mathrm{w}$ & Well II & Spring II & NT6585899107 & No \\
$\mathrm{x}$ & Well III & St Andrew's Well & NT6590998880 & No \\
$\mathrm{y}$ & Well IV & St John's Well & NT6603498827 & No \\
$\mathrm{z}$ & Well V & Pilgrims Well & NT6538799363 & No \\
$\mathrm{aa}$ & & Ladies Well & NT6567599278 & Yes \\
$\mathrm{bb}$ & & Sheep Well & NT6565999255 & Yes \\
& & West Braes Pond 1 & & \\
\hline
\end{tabular}

Table 1. Freshwater habitats on the Isle of May, Scotland. 
Station bb. West Braes Pond 2 (6.6 m x $5.3 \mathrm{~m} ; 0.1 \mathrm{~m}$ deep) is a roughly triangular shaped, shallow pond located to the south west of West Braes Pond 1. At the time of sampling the water was clear, and the bed was comprised of fine silt. There are numerous docks (Rumex sp.) growing in, and around the edge of the pond, together with patches of ivy-leaved crowfoot (Ranunculus hederaceus) and common water starwort.

Access to some areas of the island was restricted due to nesting birds and scientific studies being undertaken. In particular the island of Rona that lies to the north of the main island was off limits due to a long-term research project. Similarly, sampling was not possible at pond c at NT6524599480 due to roosting gulls (Larus sp.).

The methods used during this survey were similar to those of Maitland (1967). A standard Freshwater Biological Association (FBA) pattern hand-net was used to collect invertebrates from the substrate and submerged and emergent vegetation. Standardised monitoring using the methods developed for the National Pond Survey (Pond Action, 1998) was not possible due to the shallowness of the water and soft sediments in some of these ponds. Instead, the sediments were lightly disturbed, and the net swept through the water to collect dislodged invertebrates. The time taken for sampling varied between locations, depending on the size of the water body and the complexity of the habitat, but was generally within one to three minutes. The resulting sample of invertebrates, mixed with plant material, mineral particles and detritus, was placed in a large white tray and sorted on the bankside. Specimens that could be identified on site were released. For specimens that needed further examination they were placed in tubes with 70\% isopropanol and were labelled with the location, collection method and date. Specimens were identified to family, genus or species at a later date away from the island by examination under a stereomicroscope with reference to appropriate taxonomic books and keys. In some cases, it was impossible to identify damaged or immature specimens and these were recorded at the most appropriate taxonomic precision.

\section{RESULTS}

A total of 17 freshwater invertebrate taxa were recorded during these surveys (Table 2). This was considerably fewer than the 29 species reported by Maitland (1967). In particular, this study recorded only three species of crustacean and five species of water beetle, whereas the previous survey recorded six and eight species respectively. Nevertheless, several novel species were recorded during the current study. The water flea Daphnia magna was collected from five ponds and the water beetle Hydroporus planus was recorded from four ponds. The most novel species recorded were aquatic bugs (Hemiptera), with Corixa punctata, Callicorixa wollastoni, and Sigara stagnalis each being recorded on one occasion only. Finally, the New Zealand mud snail (Potamopyrgus antipodarum) was recorded new to the island from West Braes Pond 1 (aa). This is a non-native species, which is known from brackish water, but which has successfully colonised a range of freshwater habitats throughout Great Britain (Macan, 1977).

Midge larvae (family Chironomidae) were recorded from six ponds and worms (Oligochaeta) from three ponds. However, these were not identified further, so several species may be present. The flatworm Procerodes littoralis was re-recorded from the Loch.

A single species of freshwater shrimp (Amphipoda) was recorded during the surveys. Gammarus duebeni is a brackish water species, which is typically found on rocky shores in pools near to high water that have a freshwater influence (Gledhill et al., 1993). Two species of water flea (Cladocera) were recorded during the freshwater surveys. Daphnia magna is known to be tolerant of brackish conditions and is often found in rock pools (Hanski \& Ranta, 1983), while D. obtusa favours nutrient-enriched pools, particularly those frequented by wildfowl (Fryer, 1985).

Five species of very commonly recorded water beetles were recorded during this study, the most commonly encountered being Hydroporus planus, which is new to the island since 1958. Four species of water beetle recorded in 1958 were not re-found.

The aquatic bugs were the most speciose order, with six species all from the family Corixidae recorded. Across the two studies this brings the number of aquatic bug species recorded from the island to nine.

\section{DISCUSSION}

This study has provided an update on the freshwater invertebrate fauna of the Isle of May. Since 1958 the freshwater invertebrate fauna of the Isle of May appears to have diminished considerably. Of the 29 taxa recorded by Maitland (1967) only 12 were recorded in the present study. The reason for this reduction is not clear. However, the temporary nature of many of the water bodies and the limited colonisation opportunities available are probably key factors. In addition, the surveys undertaken were limited by the amount of time spent on the island as only one visit was made for three days in early August. Being present at one specific time of the year will ultimately miss recording species that are only found either before or after this period of time. The previous study was undertaken in late June and it is possible that the species composition was influenced by the timing of the surveys.

Despite the distance from the mainland, six species were recorded as new to the island in this study. These species can be separated into two categories based on their possible colonisation mechanism: those that probably arrived naturally by flying from the mainland (Corixa punctata, Callicorixa wollastoni, Sigara stagnalis, and Hydroporus planus); and those that probably arrived either as eggs or adults amongst the plumage of bird species visiting the island (Daphnia magna and Potamopyrgus antipodarum). Several authors have demonstrated that aquatic invertebrates can travel long distances in the latter fashion, potentially allowing the 


\begin{tabular}{|c|c|c|c|c|c|c|c|c|c|c|c|c|c|c|c|c|c|c|c|c|c|c|c|c|}
\hline Class/Order & Family & Species & $\mathbf{a}$ & $\mathbf{b}$ & d & e & $\mathbf{f}$ & g & $\mathbf{h}$ & $\mathbf{i}$ & $\mathbf{j}$ & $\mathbf{k}$ & 1 & $\mathbf{m}$ & $\mathbf{n}$ & $\mathbf{0}$ & $\mathbf{r}$ & $\mathbf{s}$ & $\mathbf{t}$ & $\mathbf{u}$ & $\mathbf{w}$ & $\mathbf{x}$ & aa & bb \\
\hline Amphipoda & Gammaridae & Gammarus duebeni & $\bullet$ & & & & & & & & & & & & & & $x$ & & & & $x$ & $x$ & 0 & 0 \\
\hline Annelida & Oligochaeta & - & $\bullet$ & $x$ & & & & & $\mathbf{x}$ & & $\bullet$ & & & & & & $x$ & $\mathbf{x}$ & $x$ & $x$ & & & & \\
\hline Arachnida & Hydracarina & - & & & & & & & & & & & & $x$ & & & & & & & & & & \\
\hline Bivalvia & Sphaeriidae & Pisidium casertanum & & & & & & & & & & & & & & & & & & & & & & \\
\hline Cladocera & Daphniidae & Daphnia magna & & & & & & & & 0 & 0 & & & & 0 & & & & & & & & 0 & 0 \\
\hline Cladocera & Daphniidae & Daphnia obtusa & & & & & & & & 0 & $x$ & $x$ & $\mathbf{x}$ & $x$ & & & & & & & & & & \\
\hline Cladocera & Eurycercidae & Chydorus sphaericus & & & & & & & & & & $x$ & $x$ & $x$ & $x$ & $x$ & $x$ & & $x$ & & & & & \\
\hline Cladocera & Macrothricidae & Macrothrix hirsuticornis & & $x$ & & & & & & & & & & $x$ & $x$ & & & & & & & & & \\
\hline Coleoptera & Dytiscidae & Agabus bipustulatus & $x$ & $x$ & & & & & $\mathbf{x}$ & & $\mathbf{x}$ & $x$ & $x$ & $\mathbf{x}$ & & $x$ & $x$ & $x$ & $x$ & $x$ & & & & \\
\hline Coleoptera & Dytiscidae & Agabus nebulosus & & & & & & & $\mathbf{x}$ & & 0 & & 0 & 0 & & & & & & & & & & \\
\hline Coleoptera & Dytiscidae & Colymbetes fuscus & & & & & & & & & & $\bullet$ & & $x$ & & & & & & & & & & \\
\hline Coleoptera & Dytiscidae & Hydroporus planus & & & & 0 & 0 & & & & & & & 0 & 0 & & & & & & & & & \\
\hline Coleoptera & Dytiscidae & Hydroporus pubescens & $x$ & $x$ & 0 & & 0 & & $\mathbf{x}$ & & $x$ & - & $\mathbf{x}$ & $x$ & & $\mathbf{x}$ & $x$ & $\mathbf{x}$ & $x$ & $x$ & & & & \\
\hline Coleoptera & Helophoridae & Helophorus flavipes & & & & & & & & & & & $x$ & & & & $\mathbf{x}$ & & & & & & & \\
\hline Coleoptera & Hydrophilidae & Anacaena limbata & & & & & & & & & & & & & $x$ & $x$ & & & & & & & & \\
\hline Coleoptera & Hydrophilidae & Hydrobius fuscipes & & & & & 0 & & & & & & & & & $x$ & & & & & & & & \\
\hline Coleoptera & Hydrophilidae & Laccobius bipunctatus & & & & & & & & & & & & & & $x$ & & & & & & & & \\
\hline Gastropoda & Hydrobiidae & Potamopyrgus antipodarum & & & & & & & & & & & & & & & & & & & & & 0 & \\
\hline Gastropoda & Lymnaeidae & Galba truncatula & & & & & & & & & & & & & & & & & $x$ & & & & & \\
\hline Hemiptera & Corixidae & Arctocorisa germari & & & & & & & $x$ & & & & & & & & & & & & & & & \\
\hline Hemiptera & Corixidae & Callicorixa praeusta & & & 0 & & & & $\mathbf{x}$ & & $\bullet$ & $x$ & $\mathbf{x}$ & & $x$ & & & & & & & & & \\
\hline Hemiptera & Corixidae & Callicorixa wollastoni & & & 0 & & & & & & & & & & & & & & & & & & & \\
\hline Hemiptera & Corixidae & Corixa punctata & & & & & & & & & & & & 0 & & & & & & & & & & \\
\hline Hemiptera & Corixidae & Sigara falleni & & & & & & & $x$ & & & & & & & & & & & & & & & \\
\hline Hemiptera & Corixidae & Sigara lateralis & & & 0 & & & & & 0 & $\mathbf{x}$ & & $\mathbf{x}$ & $\bullet$ & & & & & & & & & 0 & 0 \\
\hline Hemiptera & Corixidae & Sigara nigrolineata & & & & & & & $x$ & 0 & $\mathbf{x}$ & & & $\mathbf{x}$ & & $x$ & $x$ & & & & & & & \\
\hline Hemiptera & Corixidae & Sigara stagnalis & & & 0 & & & & & & & & & & & & & & & & & & & \\
\hline Hemiptera & Notonectidae & Notonecta glauca & & & & & & & $\mathbf{x}$ & & & & & $\mathbf{x}$ & & & & & & & & & & \\
\hline Nematomorpha & Gordiidae & Gordius sp. & & & & & & & & & & & & & & & & $x$ & & & & & & \\
\hline Ostracoda & Cyprididae & Heterocypris incongruens & & $x$ & & & & & & & & $\mathbf{x}$ & & & & $\mathbf{x}$ & & & & & & & & \\
\hline Platyhelminthes & Dalyelliidae & Dalyellia sp. & & & & & & & & & & $x$ & & & & & & & & & & & & \\
\hline Platyhelminthes & Procerodidae & Procerodes littoralis & $\bullet$ & & & & & & & & & & & & & & & & & & & & & \\
\hline Trichoptera & Phryganeidae & - & & & & & & & & & & & & $x$ & & & & & & & & & & \\
\hline
\end{tabular}

Table 2. Taxa recorded from the Isle of May, Scotland. $\mathbf{X}=$ recorded by Maitland (1967) only; $\mathbf{O}=$ recorded in this study only; $\bullet=$ recorded in both studies. 
colonisation of remote locations (e.g. Figuerola et al., 2005; Green \& Figuerola, 2005; Wesselingh et al., 1999).

Although Maitland (1967) believed that the springs on the island were permanent, at the time of this study these springs were not flowing. The majority of other freshwater habitats on the island are also temporary in nature, with the associated invertebrate fauna either specially adapted to survive periods with no water (e.g. Daphnia spp. through diapause), or being capable of finding an alternative habitat (e.g. Colymbetes fuscus and Corixa punctata through having a long adult life and being able to fly). Temporary water bodies can be home to unique assemblages of aquatic invertebrates (Collinson et al., 1995). However, on the Isle of May nutrient enrichment from bird faeces likely limits the potential of the various ponds.

More permanent water bodies are indicated by species which do not exhibit these characteristics. The only examples in the current study is the flatworm Procerodes littoralis, which was recorded from the Loch (a) and the freshwater shrimp Gammarus duebeni, which was recorded from the Loch (a), and West Braes Pond 1 (aa) and 2 (bb).

The annual average air temperature in the east of Scotland has increased by $\mathrm{ca} .1^{\circ} \mathrm{C}$ over the period 1961 to 2004 (Barnett, 2006). Whilst average precipitation totals have also increased, this is mostly in the winter months with little or no change during the spring or summer (Barnett, 2006). This will likely have led to accelerated drying of temporary freshwater habitats on the Isle of May, putting further pressure on these habitats and the flora and fauna occupying them (Ewald, 2008).

\section{ACKNOWLEDGEMENTS}

The author is grateful to David Pickett and the rest of the NatureScot NNR team for facilitating access to the island, arranging accommodation during this study, and providing much information on the natural history of the Isle of May. Thanks are also due to Professor Garth Foster and Dr Hannah Robson who provided identification assistance for aquatic Coleoptera and Cladocera respectively.

\section{REFERENCES}

Barnett, C., Hossell, J., Perry, M., Procter, C. \& Hughes, G. (2006). A Handbook of Climate Trends across Scotland. SNIFFER project CC03, Scotland \& Northern Ireland Forum for Environmental Research.

Collinson, N.H., Biggs, J., Corfield, A., Hodson, M.J., Walker, D., Whitfield, M. \& Williams, P.J. (1995). Temporary and permanent ponds: an assessment of the effects of drying out on the conservation value of aquatic macroinvertebrate communities. Biological Conservation 74, 125-133. https://doi.org/10.1016/0006-3207(95)00021-U

Eggeling, W.J. (1956). Dragonflies recorded from the Isle of May. Scottish Naturalist 68, 173.
Eggeling, W.J. (1957). Dragonflies recorded from the Isle of May. Scottish Naturalist 69, 117.

Eggeling, W.J. (1960). The Isle of May. Oliver \& Boyd, Edinburgh.

Evans, W. (1912). On the occurrence of Sympetrum fonscolombii (Selys) - A dragon-fly new to the Scottish list - in the Forth Area. Scottish Naturalist $1,12-14$.

Evans, W. (1915a). Lepidoptera (moths) and other insects at Scottish lighthouses, chiefly in the Forth area. Scottish Naturalist 37, 8-12.

Evans, W. (1915b). Lepidoptera (moths) and other insects at Scottish lighthouses, chiefly in the Forth area. Scottish Naturalist 40, 84-88.

Ewald, N.C. (2008). The Impact of Climate Change on Temporary Pond Macroinvertebrate Communities. Ph.D. thesis, University of Sussex.

Figuerola, J., Green, A.J. \& Michot, T.C. (2005). Invertebrate eggs can fly: evidence of waterfowl mediated gene-flow in aquatic invertebrates. American Naturalist 165, 274-280. https://doi.org/10.1086/427092

Fryer, G. (1985). The ecology and distribution of the genus Daphnia (Crustacea: Cladocera) in restricted areas: the pattern in Yorkshire. Journal of Natural History 19, 97-128. https://doi.org/10.1080/00222938500770051

Gledhill, T., Sutcliffe, D.W. \& Williams, W.D. (1993). British Freshwater Crustacea Malacostraca: a Key with Ecological Notes. Scientific Publications No. 52. Freshwater Biological Association, Ambleside.

Green, A.J. \& Figuerola, J. (2005). Recent advances in the study of long-distance dispersal of aquatic invertebrates via birds. Diversity and Distributions $11,149-156$. https://doi.org/10.1111/j.1366-9516.2005.00147.x

Hanski, I. \& Ranta, E. (1983). Coexistence in a patchy environment: three species of Daphnia in rock pools. Journal of Animal Ecology 52, 263-279. https://doi.org/10.2307/4599

Macan, T.T. (1977). A Key to the British Fresh- and Brackish-Water Gastropods, with Notes on their Ecology. Scientific Publications No. 13. Freshwater Biological Association, Ambleside.

Maitland, P.S. (1967). The aquatic fauna of the Isle of May, Fife, Scotland. Transactions of the Dumfries \& Galloway Natural History \& Antiquarian Society 44, 16-29.

Pickett, D. \& Luurtsema, S. (2014). The Story of the Isle of May National Nature Reserve. (2nd edition). Scottish Natural Heritage, Inverness.

Pond Action (2002). A Guide to Monitoring the Ecological Quality of Ponds and Canals Using PSYM. Pond Action, Oxford.

Scott, T. (1906). A catalogue of land, fresh-water, and marine Crustacea found in the basin of the River Forth and its estuary. Proceedings of the Royal Physical Society of Edinburgh 16, 97-190, 267-386. https://doi.org/10.5962/bhl.title.53706

Wesselingh, F.P., Cadée, G.C. \& Renema, W. (1999). Flying high: on the airborne dispersal of aquatic organisms as illustrated by the distribution histories 
of the gastropod genera Tryonia and Planorbarius.

Geologie en Mijnbouw 78, 165-174.

https://doi.org/10.1023/A:1003766516646 